\title{
POVERTY IN BULGARIA: DIMENSIONS, POLICIES AND ANALYSES
}

Abstract: The article discusses poverty in Bulgaria through the prism of the correspondence between the unfavorable wellbeing rates, the implemented policy's measures and the state of analyses in the field. By presenting existing national and EU comparative statistics, analyzing policy documents and outlining limits and prevailing bias in the scientific research on the subject, it argues that the three aspects are functionally consistent and that overcoming the high levels of poverty in the country needs reconsidered and mobilizing actions aimed at: a) better consistency among policies in different fields (economic, social, tax, insurance, labor market, environmental, etc.); and b) knowledge-based development focused on adequate addressing of structural generators of poverty.

Keywords: poverty indicators; distributive and redistributive policies; active labor market measures; social assistance; anti-poverty strategy

\section{Introduction}

Poverty is a serious and persistent problem of Bulgarian society. Since joining the European Union in 2007, repeated comparative Eurostat statistics depicts high negative values of almost all significant indicators of well-being in the country and they also significantly contribute to the unfavourable averages of the Union as a whole.

Although some progress has been made within the years - the share of people at risk of poverty or social exclusion was $44.8 \%$ in 2008 decreasing to $32.5 \%$ in 2019 (Eurostat $2020 \mathrm{~g}$ ) - poverty in the country remains quite high and the highest in the EU as is proved by the share of people at risk of poverty or social exclusion in EU in 2019 (see Graph 1)

Following the general EU guidelines within the so-called Open method of coordination, Bulgaria implements some policy measures to tackle poverty issues. However the overall effect remains quite marginal. This article discusses poverty in Bulgaria on the basis of a) review of its various dimensions; b) assessment of policies undertaken, and c) questioning the policies' knowledge-base. The conclusion presents some policy proposals and recommendations for improvement.

\footnotetext{
1 mariadjeliazkova@gmail.com; perspekt@tradel.net
} 


\section{Various dimensions of poverty in Bulgaria}

Some dimensions of poverty in the country illustrate the main problems of the socio-economic situation. They also outline important directions for the necessary political actions to overcome a series of problems in the well-being of Bulgarian citizens. This section outlines main features of poverty in Bulgaria, as illustrated by the adopted EU indicators: a) high relative poverty rate; b) high levels of material deprivation; c) high share of working poor; d) high child poverty rate; e) high poverty rate among elderly; f) deep poverty pockets.

\section{a) Relative poverty}

Relative poverty, referred to as at-risk-of-poverty rate, is adopted as the official poverty line within the EU and is measured as the share of the population with incomes below $60 \%$ of the median equivalised income ${ }^{2}$. As the name suggests, it measures poverty in relation to inequality insofar as its threshold indicates a distance from the incomes of other groups in society.

The available data show that Bulgaria has maintained the at-risk-of poverty rate relatively steady and even increasing and also clearly higher in comparison with EU average and different EU member-states over the years. Table 1 shows at-risk-of-poverty rate after social transfers.

It needs to be pointed out that this is the country's EU decade, in which anti-poverty strategies and policies addressing the at-risk-of-poverty rate have been periodically officially declared and implemented. Such policies are discussed in the next section.

\section{b) Material and social deprivation}

Starting from 2014 a new EU indicator of material and social deprivation (based on 13 items) replaced the standard material deprivation indicator which the EU adopted in 2009 (defined as the proportion of people living in households confronted with at least three out of 9 deprivations). Although the data show positive dynamics over the years (decreasing from $52.4 \%$ in 2014 to $33.6 \%$ in 2019), Bulgaria is second in the share of people $(33.6 \%)$ in material and social deprivation in the EU and at a significant distance from the EU average (12.1\%) as illustrated by the material and social deprivation rate in EU in 2019 (see Graph 2)

Moreover, in terms of the share of people in severe material deprivation ${ }^{3}$ with the value of $19.9 \%$ in 2019 , the country is the first in the EU (Eurostat 2020i).

2 https://ec.europa.eu/eurostat/web/products-datasets/-/sdg_01_10: Persons are considered to be at risk of poverty after social transfers, if they have an equivalised disposable income below the riskof-poverty threshold, which is set at $60 \%$ of the national median equivalised disposable income. To take into account the impact of differences in household size and composition, the total disposable household income is "equivalised". Eurostat applies an equivalisation factor calculated according to the OECD-modified scale first proposed in 1994 - which gives a weight of 1.0 to the first person aged 14 or more, a weight of 0.5 to other persons aged 14 or more and a weight of 0.3 to persons aged $0-13$.

3 The indicator measures the share of severely materially deprived persons who have living conditions severely constrained by a lack of resources. They experience at least 4 out of 9 following deprivations items: cannot afford i) to pay rent or utility bills, ii) keep home adequately warm, iii) 
c) Share of the working poor

The rate of the working poor has been increasing since 2013 (see Graph 3.

The material and social deprivation rate of employees (16 years or over) is $21.5 \%$ in 2019 and by this indicator Bulgaria is third in the EU, after Romania with a rate of $24.5 \%$ and Greece respectively of $23.1 \%$ (Eurostat 2020f).

\section{d) Child poverty}

Around one third of Bulgarian children (less than 18 years old) live in poverty or social exclusion, the value being again the second highest after Romania as shown by the rate of children at-risk-of-poverty or social exclusion in EU in 2019 (see Graph 4 .

In addition, in severe material deprivation in 2019 are $17,4 \%$ of children less than 6 years old; $18,8 \%$ of these $6-11$ years old and $20,4 \%$ of children from 12 to 17 years old (Eurostat, 2020f).

Around one fifth of Bulgarian children live in extremely unfavorable conditions which will undoubtedly have long-term negative consequences both for them and for the whole society in the future.

\section{e) Poverty among elderly}

Another group disproportionately affected by poverty is that of the elderly. Especially pronounced is the material and social deprivation among the retired people that affects more than $50 \%$ of them.

Table 2 depicts the material and social deprivation rate of retired people.

At the same time $29.1 \%$ of retired people live in severe material deprivation (Eurostat $2020 \mathrm{j}$ ) and their survival is at risk.

\section{f) Groups at risk and poverty pockets}

A publication of the National Statistical Institute on Indicators of Poverty and Social inclusion in 2019 (NSI, 2019) provides further data in this regard:

- Depending on the labour market inclusion, the share of people in poverty is highest among the unemployed (58.9\%) and the risk of poverty for unemployed males is with 14.2 percentage points higher than that of the unemployed females;

- The risk of falling into poverty for part-time workers is approximately four times higher than that for full-time workers;

- The level of education influences the risk of in-work poverty. The highest is the relative share of the working poor with primary and no education - 55.5\%; the relative share of the poor among the working population decreases more than seven times for persons with secondary education and the share of the working poor with higher education is $2.5 \%$;

face unexpected expenses, iv) eat meat, fish or a protein equivalent every second day, v) a week holiday away from home, vi) a car, vii) a washing machine, viii) a colour TV, or ix) a telephone. The indicator is part of the multidimensional poverty index. 
- The share of working poor males is a little bit higher (9.7\%) than that of the females $(8.2 \%)$;

- According to the type of household - the highest is the relative share of the poor among one-member households over the age of 65 , single parents with children, as well as households with three or more children;

- There is a long-established ethnic selectivity: in 2019, the highest relative share of the poor is among the people who self-identify themselves as Roma $-64.8 \%$, and the lowest share - among the people who self-identify themselves as belonging to the Bulgarian ethnic group - $16.7 \%$;

- Among the poor people from the Bulgarian ethnic group, retirees predominate (55.2\%), while among the poor people from the Roma ethnic group the relative share of the unemployed is the highest (36.6\%);

- The regional disparities are also growing.

Following these lines, deep poverty pockets are established in the country with more than one fourth of the population reporting unaffordability of adequate eating (27.6\%) and of keeping homes adequately warm (30.1\%) that affect health and will probably have longterm unfavourable consequences.

This is further enhanced by the poverty persistence and its transmission from a generation to a generation. Data on persistent at-risk-of-poverty rate ${ }^{4}$ depict also higher levels than the EU average and in 2019 Bulgaria is on fourth place with a value of $16.1 \%$ after Lithuania - 19,2\%, Romania - 16,8\% and Estonia - 16,7\% (Eurostat 2020h).

Summarizing poverty in Bulgaria is characterised by its wide distribution, persistence and depth of certain poverty pockets.

\section{Policies undertaken}

In the 90s of the last century and the beginning of the first decade of this century, the problems of poverty, despite its wide scope, were largely marginalized and when discussed were basically considered as a result of individual failures. There was little or no political attention to poverty issues. Public discussions were overwhelmed by the apologetics of so-called neoliberalism and the "invisible hand of the market". Some well-established political tools, such as official calculations on incomes necessary for survival were abandoned. With the EU integration of the country a shift in the political efforts took place. An official poverty line was adopted in 2007, following EU guidelines and measuring poverty as a share of the population with an income below $60 \%$ of equivalised median income. Gradually, coherent national poverty reduction strategies started to be elaborated as well as national action plans for their implementation, official statistics on poverty and social exclusion expanded and improved providing comparative basis with the other EU Member States. National bodies were set up also, that include various stakeholders, e.g. National Consultative Council for Social Inclusion at the Council of Ministers.

Currently, on 31. 12. 2020, the Council of Ministers adopted a new National Strategy for Poverty Reduction and Promotion of Social Inclusion with a horizon until 2030. It is intended

4 The indicator shows the percentage of the population whose equivalised disposable income was below the 'at-risk-of-poverty threshold' for the current year and at least 2 out of the preceding 3 years. 
to outline a strategic framework for the development of policies related to poverty reduction and promotion of social inclusion in the next decade. It is assumed that "the main goal of the planned measures and activities is to improve the quality of life of vulnerable groups and create conditions for their full realization through adequate income support, labour market inclusion and access to quality services". According to the Strategy's vision (p. 28) "By 2030, Bulgaria is a country in which social inequalities and poverty are limited and prerequisites and conditions for inclusive and sustainable growth and opportunities for improving the quality of life of vulnerable groups are created." It is envisaged that any government policy health, social, educational, etc. will aim to reduce poverty or inequality in society.

However, this political document also retains the logic of the previous years based on "adapting social inclusion policies and ensuring the sustainability of the results achieved" (op. cit. p. 8).

There are essentially no measures and/or clear envisaged tools to reduce inequalities in terms of distributive and redistributive policies, although various stakeholders - trade unions, civil society organizations - undertake various campaigns in this direction: for adequate minimum incomes, for progressive taxation, etc. It is not clear either how the promised equal access to education and health will be achieved.

Following the already established practices, Bulgaria continues to implement two main pillars of anti-poverty policies: a) active labour market policies; and b) social assistance.

a) For years already, the public policies' emphasis has been on active labour market policies, without any attention to the quality of jobs. The logic is that employment provides opportunities to get out of poverty. However data depicts that in the period 2008 2019 the working poor have increased by 29000 people. Although it is well known that the poor quality of jobs and the lack of prospects are the main factors for people, especially young, to leave the country resulting in a very unfavourable demographic situation, there is a clear lack of political attention to salaries/wages in the jobs offered and inequalities within them. Simultaneously the leading political idea that providing any kind of job helps to lift people out of poverty is highly questionable.

Moreover, Bulgaria has a quite high Gini index before social transfers, i.e. within the primary distribution, and in particular within pay inequalities.

A comparison with the Czech Republic, for example, illustrates the high levels of employment polarization in Bulgaria (Jeliazkova, 2019). Table 3 presents the share of employees with salaries/wages as \% of the average salary in Bulgaria and Czech Republic.

The high values of the two poles in Bulgaria affect not only the quality of life and well-being of employees, but also have far-reaching consequences for building the human capital of children, for the qualities of the workforce, for the "equality of opportunities".

Due to such social structuring, again in 2019 Bulgaria is the EU country with the highest Gini index before and after the social transfers and by this indicator the country increases its distance from the other EU member states. The fact that this is result of political choices made could be illustrated by comparing Bulgaria and Ireland on the basis of the Gini indexes in Bulgaria and Ireland before and after the social transfers 2010-2019 (see Graph 5).

The Gini index before social transfers reflects different rules and norms introduced by different EU countries that affect the pay gap. Czech Republic for example keeps wage inequalities lower than the EU average over the last 20 years. Up to 2014 Ireland Gini index 
before social transfers was higher than that of Bulgaria but policies undertaken resulted in its decrease. The progressive taxation and active anti-poverty measures in Ireland, aimed, for example, at families with children, single parent families, elderly and other vulnerable groups support the redistributive effect. On the contrary, Bulgaria is among the EU countries whose public policies in distribution are extremely tense and fragment society in many non-transparent ways.

The Gini index after social transfers reflects the impact of public policies on redistribution processes. This is achieved through enlightened complexes of economic, social, tax, social security and so on policies. Ireland, for example, reduces the Gini index before social transfers by almost 19 percentage points as a result of such policies and falls in this regard under the value of EU average. Despite its relatively lower values in distributive inequalities, the Czech Republic's redistributive policy also reduced further the Gini index by 18.1 percentage points. Maintaining some of the highest inequalities in primary distribution, Bulgaria does not elaborate and implement redistributive policies and by least reducing the Gini index after social transfers remains the country with the highest inequalities in the EU.

b) On this basis, the second main pillar of anti-poverty policies in the country is the social assistance, promising effective and targeted financial and material support to those in need. In fact social assistance provides income support at very low levels, inconsistent with the incomes needed for people to survive. Although there is growing evidence of what level of income is needed for a person to survive, there is no formal link between the levels of social assistance and the cost of living.

Already, for quite a long time only a research centre at one of the two official trade unions - the Confederation of Independent Trade Unions in Bulgaria - provides data on subsistence levels.

Meanwhile there are already international sources that try to calculate the living wage and the income that a person needs to live normally in numerous countries and Bulgaria is included (Living Wage Indicator, Numbeo). However the refusal to introduce nationally adapted poverty indicators based on adequate consumer basket continues.

Despite numerous reminders from the EU in consistent country-specific recommendations and EU wide campaigns for adequate minimum incomes, the social assistance system in the country remains based on the so-called guaranteed minimum income, which is BGN 75 a month (38.35 Euro), that is below the level of the extreme world poverty indicator of $\$ 1.9$ a day. In addition, people of working age are further sanctioned if they apply to receive social assistance - they receive less than BGN 50 (25.56 Euro) per month and if and only if they agree to perform the so-called community services 14 days a month for 4 hours a day. Thus, social assistance further erodes the otherwise officially introduced minimum monthly wage, which in 2021 is BGN 650 gross (332.34 Euro) and respectively BGN 504 net (257.69 Euro).

The legal definition of the minimum guaranteed income states that it is "legally defined amount, which is used as a basis for determining the social assistance in order to ensure a minimum income to meet the basic living needs of individuals according age, marital status, health status and property" (Social Assistance Act). In practice, the guaranteed minimum income is determined annually by the Council of Ministers "according to the state's financial ability". Thus based on the guaranteed minimum income, differentiated minimum incomes are calculated, different for different categories of people, depending on age, marital status, 
disability, employment and school attendance. Additionally - there are different targeted allowances (such as targeted assistance for heating; targeted assistance to pay rent; targeted allowance for travel for the elderly; targeted assistance to certain groups of people with disabilities) and one-off benefits (to meet ad hoc health, education, utilities and other vital needs, individuals and families may be granted one-time assistance once a year; for the issuance of identity cards; to cover the costs of subsistence and accommodation for persons and their companions if a permission for treatment abroad is received by the Ministry of Health and when some costs are not included in the cost allocated for the treatment).

Because of the extremely low levels of minimum income schemes, social assistance hardly has any effect on preventing and reducing poverty. The whole system is very fragmented with a case by case design and mainly focused on some support against extreme levels of poverty. But even this minimum target is not achieved - in Bulgaria the social assistance is hardly able to provide even physical survival.

As a result of such developments Bulgaria is also among the EU countries with the slowest progress in reference with the UN Sustainable Development Goal 1 'No poverty'. Additionally, as far as the accepted goal 10 of the UN Sustainable Development Goals, related to the reduction of inequalities - "the share of income of the poorest $40 \%$ of the population to grow faster than that of other groups" - is concerned, the dynamic is in the opposite direction (Jeliazkova \& Minev, 2020), as depicted by the statistical data on the income share of the bottom 40\% of the population in Bulgaria 2006-2019 (see Graph 6.

\section{Poverty analyses and knowledge-based policies?}

Similar to the political actions, analyses of poverty and social exclusion have been largely marginalized during the first 15 years of transition. Analyses of unemployment, deindustrialization and liberalization, the pressure on social rights, human development index and some social problems were available, but scientific discussions of poverty were to a large extent undesirable and considered through the ideological bias as opposed to the ideas of market and democracy.

With the EU integration of the country and the expansion of the comparative poverty statistics, ideological pressure somehow diminished and national analyses and research grew in number, including those related to different problems of poverty, its different dimensions and manifestations, and the focus on different groups vulnerable to poverty. Simultaneously Bulgarian actors and organizations established contacts and became part of various EU wide networks (for example, EuroChild, European Anti-Poverty Network, etc.) and comparative research on specific issues emerged. The introduction of an official poverty line, the 2010 as the European Year against Poverty, the intensification of trade union activities, the establishment of various bodies related to poverty issues, such as the National Economic and Social Committee, stimulated the implementation of various studies and analyses.

The expansion and deepening of the analyses is a characteristic of the 3rd decade of the period of transition, together with the search for possible solutions to emerging problems and various proposals for changes in public policies in the field. At the same time, there is an intensification and expansion of public discussions. Various areas of social policy are increasingly the focus of research and analysis: a) labour market (Borisova-Marinova et al., 2018; Jeliazkova, Minev, Draganov, 2018; Krasteva, 2019; Jeliazkova, 2019); 
b) education (Milenkova, 2011; Kabakchieva, 2018); c) healthcare (Ivkov et al., 2017; Ivkov, 2018); d) social benefits (Grigorova, 2016; Grigorova, 2018); e) energy poverty (Zahariev et al., 2016; Peneva, 2019); f) tax policy (Minev, 2018; Pekanov, 2018), etc.

Despite such positive developments, some weaknesses of existing analyses and research could be also outlined.

A) It could be said that the descriptive nature is highly predominant in large part of the analyses. Both the national statistics and the empirical sociological surveys' results, as well as the comparative research between Bulgaria and the other EU member states, including the average values in the EU, are an extremely important basis for summaries and conclusions, as well as for developing proposals for changes. At the same time, the fragmented data, the lack of developed adequate nationally adapted definitions, indicators and data related to cost of living make it difficult to have a clear and reliable picture of poverty.

B) An important feature of data and analyses is the emphasis on poverty accompanying factors - such as level of education, employment and labor market status, composition and structure of households, settlement, ethnic selectivity, age, etc. This contributes to the fragmentation of groups and case by case or program by program assessments, but makes it difficult to develop theoretical and practical perspectives through which to significantly reduce poverty levels, which otherwise is the declared goal of policies and the meaning of research and analysis.

Although these accompanying factors are an important part of the picture of poverty in the country, discussing them as the main causes of poverty and marginalization speaks about specific selectivity of the research topics rather than gradual autonomous upgrading of research and analyses. In fact, this leads to white spots and missing indicators in research fields and limits the ability to upgrade already developed proposals and their scientific discussions.

C) There is a lack of data on some important indicators, such as subsistence poverty line; purchasing power of different incomes; inequalities within certain groups like Roma, men, women, inequalities 90/10; inequalities 99/1; wealth concentration, etc. Such lack of data does not provide a sufficient basis for further upgrading of research and analyses.

D) There are not enough scientific evaluations on the consistency of anti-poverty policies with other types of policies - such as economic, energy, environmental, financial, regional and agricultural.

E) At the same time, available poverty analyses and proposals based on them do not find a sufficient place either in scientific discussions, nor are they applied in the implemented policies. Thus the possibilities for scientific analyses on important issues are rather restricted. An example of this is the fact that the current scientific programs (adopted in 2018) that claim to create conditions for searching and finding solutions to current and significant social challenges do not address wellbeing issues ${ }^{5}$. Despite the fact that Bulgaria is

\footnotetext{
5 Adopted national research programs include: "Information and communication technologies for a single digital market in science, education and security"; "Low carbon energy for transport and households"; "Environmental protection and reducing the risk of adverse events and natural disasters"; "Healthy foods for a strong bio economy and quality of life"; "Cultural and historical heritage, national memory and social development"; "Electronic healthcare"; "Reproductive biotechnologies in livestock breeding".
} 
clearly among the countries with the most unfavorable levels in most indicators of well-being these challenges have not been turned into priority scientific questions, at least as far as the national research programs are concerned.

F) In addition, there seems to exist a demotivating effect as long as there are no clear mechanisms for translating scientific results into practical actions. The lack of independent assessments of the situation and of the implemented policies, as well as the lack of the so-called participatory action research, with the participation of the interested people and stakeholders, discourages scientific research into these problems.

G) The main result of such a combination of mostly descriptive analyses, emphasis on the already mentioned accompanying factors, fragmented assessment on different labor market measures and social assistance schemes, knowledge restrictions through financial and implementation flows limits the knowledge on the main poverty generators and how they should be addressed.

Following the prevailing bias it seems that the dimensions of poverty in Bulgaria, the policies implemented and to some extent the quality of analyses are in functional correspondence and somehow they support each other.

\section{Conclusion and policy recommendations}

Bulgaria has quite severe problems with poverty and social exclusion, with the deep marginalization of certain groups and poverty persistence through its transfer from a generation to a generation. As illustrated in the first part of this article, the policy measures undertaken do not contribute significantly to overcoming poverty and social exclusion in the country. In this regard, the inadequacy of available political measures needs to be recognized and instead to adapt existing policies, they have to be radically revised. An important reason for this is that although rarely discussed, the main generators of poverty in the country are a series of policies - economic, financial, educational, health, tax and social security policies, and the relationships between them. On this basis, certain aspects of social policy do try to mitigate the unfavorable processes caused by other policies and act as a last resort by supporting people with lowest incomes and providing extremely low level of benefits.

In order to overcome these problems, a clear consistency between the different policies is needed, based on adequate welfare and wellbeing indicators and aimed at poverty generators and pro-poor development. In this regard, a targeted review, analysis and evaluation of various policies should be carried out and independent social impact assessments could contribute to decisive improvements in all phases of the policy cycle (agenda setting, goals and aims identification, developing adequate policy instruments for their achievement, implementation of these instruments, constant monitoring and introduction of improvements, evaluations and scientific analysis how to address poverty generators).

A move from policy-driven knowledge to knowledge-based policies could provide holistic, integrated and people-oriented development with adequate anti-poverty actions. 
Марија Д. Желиазкова ${ }^{1}$

Бугарска академија наука,

Институт за филозофију и социологију,

Одељење за јавну политику и друштвене промене

Софија (Бугарска)

\title{
СИРОМАШТВО У БУГАРСКОЈ: ДИМЕНЗИЈЕ, ПОЛИТИКЕ И АНАЛИЗЕ
}

\author{
(Превоg In Extenso)
}

Сажетак: Овај чланак сагледава сиромаштво у Бугарској кроз призму односа између неповољних стопа благостања, спроведених политичких мера и стања анализе у овој области. Представљајући постојеће националне и упоредне ЕУ статистичке, анализирајући документа политике и утврђујући ограничења и превладавајуће предрасуде у научном истраживању о овој теми, тврди се да су три аспекта функционално доследна и да превазилажење високих стопа сиромаштва у земљи треба поново размотрити и организовати активности чији је циљ: а) већа доследност између политика у разним областима (економија, социјална питања, порези, осигурање, тржиште рада, заштита животне средине итд.) и б) развој заснован на знању и усмерен на адекватно бављење структуралним генераторима сиромаштва.

Кључне речи: показатељи сиромаштва; дистрибутивне и редистрибутивне политике; активне мере тржишта рада; социјална помоћ; стратегија против сиромаштва

\section{Увод}

Сиромаштво је озбиљан и континуиран проблем бугарског друштва. Од приступања Европској унији 2007. године, неколико упоредних извештаја Статистичког уреда европских заједница (Eurostat) стално показује високе негативне вредности готово свих значајних показатеља благостања у Бугарској, што знатно доприноси и неповољном просеку Европске уније у целини.

Иако је током година постигнут извесни напредак - удео људи изложених ризику од сиромаштва или социјалне искључености је 2008. износио 44,8\%, да би се до 2019. смањио на 32,5\% (Eurostat 2020g) - сиромаштво у земљи и даље је прилично велико, а највеће у читавој ЕУ. То доказује удео људи изложених ризику од сиромаштва или социјалне искључености у ЕУ током 2019. године (видети Графикон 1)

Поштујући опште смернице ЕУ у оквиру такозваног Отвореног метода координације, Бугарска спроводи одређене политичке мере у вези са питањима сиромаштва.

1 mariadjeliazkova@gmail.com; perspekt@tradel.net 
Међутим, целокупан ефекат и даље је сасвим маргиналан. Овај чланак говори о сиромаштву у Бугарској на основу а) прегледа разних димензија; б) процене предузетих политика и в) испитивања базе знања тих политика. Закључак даје предлоге одређених политика и препоруке за побољшање.

\section{Разне димензије сиромаштва у Бугарској}

Поједине димензије сиромаштва у земљи илуструју главне проблеме друштвено-економске ситуације. Оне такође у кратким цртама представљају важне правце за неопходно политичко деловање ради превазилажења низа проблема у благостању становника Бугарске. У овом раду дате су главне карактеристике сиромаштва у Бугарској на основу усвојених индикатора ЕУ: а) висока стопа релативног сиромаштва; б) високи нивои материјалне ускраћености; в) велики удео сиромашног радног становништва; г) висока стопа сиромаштва међу децом; д) висока стопа сиромаштва међу старим људима; ђ) велики џепови сиромаштва.

\section{а) Релативно сиромаштво}

Релативно сиромаштво, познато као стопа ризика од сиромаштва, усвојено је као званична линија сиромаштва у оквиру ЕУ и мери се на основу удела становништва са приходима испод $60 \%$ средњег прилагођеног прихода ${ }^{2}$. Као што и сам назив каже, овим се мери сиромаштво у вези са неједнакошћу, при чему праг сиромаштва указује на то колико неки људи заостају за приходима осталих група у друштву.

Доступни подаци показују да је стопа ризика од сиромаштва у Бугарског већ годинама прилично стабилна или у порасту, а упадљиво виша у поређењу са просеком у ЕУ и разним државама чланицама ЕУ. У Табели 1 дата је стопа ризика од сиромаштва са тачком пресека: $60 \%$ средњег прилагођеног прихода после социјалних трансфера.

Треба нагласити да је од приступања земље ЕУ прошла једна деценија, током које су периодично утврђиване и спровођене званичне стратегије против сиромаштва и политике које се баве стопом ризика од сиромаштва. О тим политикама биће речи у наредном одељку.

\section{б) Материјална и социјална ускраћеност}

Године 2014. нови ЕУ показатељ материјалне и социјалне ускраћености (заснован на 13 ставки) заменио је стандардни показатељ материјалне ускраћености који је ЕУ усвојила 2009 (дефинисан као сразмера особа који живе у домаћинству које је лишено најмање три од девет ставки).

\footnotetext{
${ }^{2}$ https://ec.europa.eu/eurostat/web/products-datasets/-/sdg_01_10: Особе за које се сматра да су изложене ризику од сиромаштва после социјалних трансфера, ако имају прилагођен расположиви приход испод прага ризика од сиромаштва који износи $60 \%$ националног средњег прилагођеног расположивог прихода. Када се узме у обзир утицај разлика у величини и саставу домаћинстава, укупан расположиви приход у домаћинству се „прилагођава”. Eurostat примењује фактор прилагођавања који се обрачунава према модификованој OECD скали која је први пут предложена 1994 - а који даје пондер од 1,0 првој особи од старој 14 година и више, пондер од 0,5 осталим особама старим 14 година и више, и пондер од 0,3 особама старости $0-13$ година.
} 
Иако подаци показују позитивну динамику током година (смањење са 52,4\% у 2014. на 33,6\% у 2019), Бугарска је на другом месту у ЕУ по уделу људи у материјалној и социјалној ускраћености (33,6\%) и далеко од просека ЕУ $(12,1 \%)$, о чему говори стопа материјалне и социјалне ускраћености у ЕУ у 2019. години (Графикон 2).

Осим тога, када је реч о проценту људи који живе у тешкој материјалној беди односно 19,9\% у 2019, земља је на првом месту у ЕУ (Eurostat 2020i).

\section{в) Удео сиромашног радног становништва}

Стопа сиромашног радног становништва непрекидно расте од 2013. године (видети Графикон 3),

Стопа материјалне и социјалне ускраћености запослених (од 16 година старости навише) износила је 21,5\% у 2019. години, а према овом показатељу Бугарска је на трећем месту у ЕУ, после Румуније са стопом од $24,5 \%$ и Грчке са стопом од 23,1\% (Eurostat 2020f).

\section{г) Сиромаштво међу децом}

У Бугарској отприлике трећина деце (млађе од 18 година) живи у сиромаштву или социјалној искључености, због чега је на другом месту у ЕУ, после Румуније, што потврђује стопа деце изложене ризику од сиромаштва или социјалне искључености у 2019 (Графикон 4)

Осим тога, у тешкој материјалној беди је 2019. године живело 17,4\% деце млађе од 6 година; 18,8\% деце узраста од 6 до 11 година и 20,4\% деце узраста од 12 до 17 година (Eurostat, 2020f).

Отприлике петина деце у Бугарској живи у крајње неповољним условима, што ће несумњиво имати дугорочне негативне последице како по њих, тако и по читаво друштво у будућности.

\section{д) Сиромаштво међу старим људима}

Стари људи су још једна група која је несразмерно погођена сиромаштвом. Посебно је упадљива материјална и социјална беда међу пензионерима, која погађа више од $50 \%$ њих.

Табела 2 приказује стопу материјалне и социјалне беде међу пензионерима.

У исто време, 29,1\% пензионера живи у условима тешке материјалне ускраћености (Eurostat 2020j), па је њихово преживљавање угрожено.

3 Овај показатељ мери удео особа са тешким материјалним стањем, које живе у озбиљно ограниченим условима услед недостатка средстава. Они су лишени најмање 4 од следећих 9 ставки: i) не могу да плате станарину или рачуне, ii) немају адекватно грејање код куће, iii) не могу да покрију непланиране трошкове, iv) не могу да једу месо, рибу или сличне изворе протеина сваког другог дана, v) не могу да оду на једнонедељни одмор, vi) не могу да приуште аутомобил, vii) не могу да приуште машину за веш, viii) не могу да приуште телевизор у боји, или іх) не могу да приуште телефон. Овај показатељ је саставни део вишедимензионалног индекса сиромаштва. 
ђ) Ризичне групе и џепови сиромаштва

Публикација Националног завода за статистику о показатељима сиромаштва и социјалне искључености у 2019 (NSI, 2019) пружа додатне податке о овом проблему:

- Због зависности од укључивања на тржиште рада, проценат сиромашних највиши је међу незапосленима (58,9\%), а ризик од сиромаштва је код незапослених мушкараца за 14,2 процентних поена већи него код незапослених жена;

- Ризик од осиромашења хонорарних радника приближно је четири пута већи него за оне са сталним запослењем;

- Ниво образовања утиче на ризик сиромаштва запослених. Највећи је релативни удео сиромашних запослених са основним образовањем или без икаквог образовања - 55,5\%; релативни удео сиромашних међу радним становништвом опада више од седам пута за особе са средњошколским образовањем, док удео сиромашних запослених са вишим образовањем износи 2,5\%;

- Удео сиромашних запослених мушкараца нешто је већи (9,7\%) у поређењу са женама $(8,2 \%)$;

- Према типу домаћинства, највећи је релативни удео сиромашних у једночланим домаћинствима особа старијих од 65 година, у домаћинствима самохраних родитеља са децом, као и домаћинствима са двоје или више деце;

- Већ дуго времена постоји етничка селективност: током 2019. је највећи релативни удео сиромашних забележен међу људима који се изјашњавају као Роми - 64,8\%, док је најмањи удео од 16,7\% забележен међу људима који се изјашњавају као припадници бугарске етничке групе;

- Међу сиромашнима из бугарске етничке групе на првом месту су пензионери $(55,2 \%)$, док је највећи релативни удео незапослених (36.6\%) међу сиромашнима из ромске етничке групе;

- Такође се повећавају регионалне разлике.

На основу горе наведеног, огромни џепови сиромаштва појавили су се у земљи где више од четвртине становника не може себи да приушти адекватну исхрану $(27,6 \%)$ и одговарајуће грејање код куће $(30,1 \%)$, што утиче на здравље и вероватно ће имати дугорочне неповољне последице.

Ово је додатно отежано сталним сиромаштвом и његовим преношењем са генерације на генерацију. Подаци о сталној стопи ризика од сиромаштва ${ }^{4}$ такође говоре о вишим нивоима од просека ЕУ, при чему је Бугарска била на четвртом месту 2019. са 16,1\%, после Литваније са 19,2\%, Румуније са 16,8\% и Естоније са 16,7\% (Eurostat 2020h).

У кратким цртама, карактеристике сиромаштва у Бугарској су широка распрострањеност, континуитет и дубина одређених џепова сиромаштва.

4 Овај показатељ даје проценат становништва чији је еквивалентни расположиви приход био испод прага ризика од сиромаштва у текућој години и најмање 2 од претходне 3 године. 


\section{Примењене политике}

Деведесетих година 20. века и почетком прве деценије 21. века, проблеми сиромаштва, упркос његовој широкој распрострањености, у великој мери су маргинализовани, а и када су били предмет расправе, углавном су посматрани као резултат појединачних неуспеха. Питањима сиромаштва поклањало се недовољно или нимало политичке пажње. Јавне расправе биле су преплављене апологетиком такозваног неолиберализма и „невидљиве руке тржишта”. Одбачена су нека устаљена политичка средства, као што су званични обрачуни прихода неопходног за преживљавање. Након приступања земље Европској унији уследио је помак у политичким напорима. Године 2007. усвојена је званична линија сиромаштва у складу са смерницама ЕУ и мерење сиромаштва као удела становника са приходима испод $60 \%$ средњег прилагођеног прихода. Постепено су почеле да се разматрају кохерентне националне стратегије за смањење сиромаштва, као и национални акциони планови за њихово спровођење, док су званичне статистике о сиромаштву и социјалној искључености проширене и унапређене, дајући на тај начин основ за упоређивање са осталим чланицама ЕУ. Формирана су и национална тела која окупљају разне заинтересоване учеснике, нпр. Национално саветодавно веће за социјално укључивање при Савету министара.

У најновије време, тачније 31. 12. 2020, Савет министара је усвојио нову Националну стратегију за смањење сиромаштва и промоцију социјалне укључености до 2030. године. Намера је да се да нацрт стратешког оквира за развој политика у вези са смањењем сиромаштва и промоцијом социјалне укључености током следеће деценије. Претпоставља се да је „главни циљ планираних мера и активности побољшати живот осетљивих група и створити услове за њихову потпуну реализацију путем адекватне подршке у приходима, укључивања у тржиште рада и приступа квалитетним услугама”. Према визији ове стратегије (стр. 28), „до 2030. године Бугарска ће бити земља у којој ће социјалне неједнакости и сиромаштво бити ограничени, док ће се створити предуслови и услови за инклузивни и одржив развој и прилике за унапређење квалитета живота осетљивих група”. Предвиђено је да све државне политике - здравствена, социјална, образовна итд. - имају за циљ смањење сиромаштва односно неједнакости у друштву.

Међутим, овај политички документ такође задржава логику из претходног периода засновану на „прилагођавању политика социјалне укључености и обезбеђивања одрживости постигнутих резултата” (Ibid, стр. 8).

У суштини не постоје никакве мере односно јасно предвиђени инструменти за смањење неједнакости у смислу дистрибутивних и редистрибутивних политика, иако поједине заинтересоване стране - синдикати, организације цивилног друштва - покрећу разне кампање чији су циљеви: адекватан минимални приход; прогресивно опорезивање итд. Није јасно ни како ће бити остварен обећани равноправни приступ образовању и здравственим услугама.

Придржавајући се претходно установљене праксе, Бугарска наставља да спроводи два главна стуба политике против сиромаштва, а то су: а) активна политика тржишта рада и б) социјална помоћ. 
a) Већ годинама се нагласак јавне политике ставља на активну политику тржишта рада, при чему се никаква пажња не поклања квалитету послова. Логика је да запослење пружа прилике за излазак из сиромаштва. Међутим, подаци показују да је број сиромашних запослених порастао за 29.000 људи у периоду 2008-2019. године. Иако је добро познато да лош квалитет послова и недостатак перспективе за будућност представљају два главна фактора за одлазак из земље, нарочито када је реч о младим људима, тако доводећи до веома неповољне демографске ситуације, очигледан је недостатак политичке пажње у вези са платама/надницама за понуђене послове и неједнакостима које постоје између њих. Истовремено, крајње је дискутабилна водећа политичка идеја да ће обезбеђивање било каквог посла помоћи људима да се ослободе сиромаштва.

Осим тога, Бугарска има прилично висок Ђини коефицијент пре социјалних трансфера, тј. у оквиру примарне дистрибуције, а нарочито у оквиру неједнакости у платама.

Поређење са Чешком Републиком, на пример, илуструје високе нивое поларизације запослења у Бугарској (Jeliazkova, 2019). у Табели 3 дат је удео запослених са платама/надницама као проценат просечних примања у Бугарској и Чешкој Републици.

Високе вредности поларизованих страна у Бугарској утичу не само на квалитет живота и благостање запослених, већ имају и далекосежне последице у изградњи људског капитала, односно деце, у квалитету радне снаге и у „једнаким могућностима”.

Због овакве социјалне структуре, Бугарска је и 2019. била чланица ЕУ са највећим Ђини коефицијентом пре и после социјалних трансфера, а према овом показатељу земља повећава свој заостатак за осталим чланицама ЕУ. Чињеница да је ово резултат донетих политичких избора може се илустровати поређењем Бугарске и Ирске на основу њихових Ђини коефицијената пре и после социјалних трансфера у периоду 2010-2019. године (видети Графикон 5).

Ђини коефицијент пре социјалних трансфера одражава различита правила и норме у различитим земљама ЕУ која утичу на разлике у платама. У Чешкој Републици, на пример, неједнакост плата је на нижем нивоу од просека ЕУ током последњих 20 година. Ђини коефицијент у Ирској је до 2014, пре социјалних трансфера, био виши него у Бугарској, али су предузете политике утицале на његово смањење. Прогресивно опорезивање и активне мере против сиромаштва који су у Ирској, на пример, предвиђени за породице са децом, породице са једним родитељем, старе особе и остале осетљиве групе становништва, подржавају редистрибутивни ефекат. Насупрот томе, Бугарска је једна од чланица ЕУ чије су јавне политике у дистрибуцији изузетно напете и деле друштво на вишеструке нетранспарентне начине.

Ђини коефицијент после социјалних трансфера одражава утицај јавних политика на процесе редистрибуције. Ово се постиже унапређеним системима економских, социјалних, пореских политика, социјалног осигурања и других политика. Ирска је, на пример, смањила Ђини коефицијент пре социјалних трансфера за готово 10 процентних поена захваљујући таквим политикама и у том погледу је испод просечне вредности овог коефицијента у ЕУ. Упркос релативно ниским вредностима дистрибутивних неједнакости, редистрибутивна политика Чешке 
Републике такође је додатно смањила Ђини коефицијент за 18,1 процентних поена. Задржавајући неке од највећих неједнакости у примарној дистрибуцији, Бугарска не разматра нити спроводи редистрибутивне политике, а са најмањим падом Ђини коефицијента после социјалних трансфера, Бугарска је и даље земља са највећим неједнакостима у ЕУ.

б) На тој основи, други главни стуб политике против сиромаштва у земљи јесте социјална помоћ, која обећава ефикасну и циљану финансијску и материјалну подршку онима којима је то неопходно. У стварности, социјална помоћ пружа веома низак ниво подршке приходима која није у складу са приходима који су људима неопходни за преживљавање. Иако постоји све више доказа о неопходном нивоу прихода за преживљавање, не постоји званична повезаност између износа социјалне помоћи и трошкова живота.

Већ одређено време само један истраживачки центар обезбеђује податке о нивоу средстава потребних за живот. Овај центар припада једном од два званична синдиката - Савезу независних синдиката у Бугарској.

С друге стране, постоје и међународни извори који покушавају да израчунају минималну надницу и приходе потребне за нормалан живот у бројним земљама, међу којима је и Бугарска (Living Wage Indicator, Numbeo). Међутим, и даље се одбија увођење национално прилагођених показатеља сиромаштва на основу одговарајуће потрошачке корпе.

Упркос многобројним подсећањима ЕУ на доследне препоруке за конкретне земље и свеобухватним кампањама ЕУ за одговарајућу минималну цену рада, систем социјалне помоћи у Бугарској и даље почива на такозваном гарантованом минималном дохотку који износи 75 лева месечно (38,35 евра), што је испод нивоа светског показатеља екстремног сиромаштва од 1,9 долара дневно. Поред тога, радно способни људи додатно су санкционисани ако се пријаве за социјалну помоћ - добијају мање од 50 лева (25,56 евра) месечно и то само ако пристану да обављају такозвани друштвено користан рад 14 дана месечно, по 4 сата дневно. На овај начин социјална помоћ додатно смањује званично уведену минималну месечну плату, која за 2021. износи 650 лева бруто (332,34 евра), односно 504 лева нето (257,69 евра).

Према закону, минимални загарантовани доходак је „законски дефинисан износ који се користи као основица за одређивање социјалне помоћи у циљу обезбеђивања минималног прихода за покривање основних животних потреба појединаца према годинама живота, брачном статусу, здравственом стању и имовини" (Закон о социјалној помоћи). У пракси, загарантовани минимални доходак одређује једном годишње Савет министара „према финансијској способности државе”. Стога, на основу загарантованог минималног дохотка се обрачунавају диференцирани минимални износи за различите категорије људи, у зависности од година живота, брачног статуса, инвалидитета, запослења и похађања образовне установе. Осим тога, постоје и разне циљане накнаде (као што су: помоћ за грејање, помоћ за станарину; помоћ за путовање старијим особама; помоћ одређеним групама особа са инвалидитетом) и једнократне бенефиције (појединцима и породицама некада се исплаћује једнократна помоћ за покривање конкретних здравствених, образовних и осталих кључних потреба и плаћање рачуна; за покривање трошкова издржавања и смештаја 
особама и њиховим пратиоцима у случају да добију дозволу Министарства здравља за лечење у иностранству, као и када неки трошкови нису укључени у износ додељене помоћи за лечење).

Због изузетно ниског нивоа шеме минималног дохотка, социјална помоћ једва има неког утицаја на спречавање и смањење сиромаштва. Читав систем је крајње подељен јер почива на појединачним случајевима и углавном је усредсређен на подршку против екстремних нивоа сиромаштва. Но, чак ни овај зацртани минимални износ није остварен - социјална помоћ у Бугарској готово да не може да испуни захтеве за физичким преживљавањем.

Услед оваквих трендова, Бугарска је међу чланицама ЕУ са најспоријим напретком у вези са 1. циљем одрживог развоја УН: „Без сиромаштва”. Исто тако, када је реч о прихваћеном 10. циљу одрживог развоја УН, који се односи на смањење неједнакости - „удео прихода најсиромашнијих 40\% становника треба да расте брже него у другим групама" - динамика се одвија у супротном смеру (Jeliazkova \& Minev, 2020), што показују статистички подаци о уделу прихода најсиромашнијих $40 \%$ становништва Бугарске у периоду 2006-2019. (Графикон 6).

\section{Анализа сиромаштва и политике засноване на знању?}

Слично политичком деловању, анализе сиромаштва и социјалне искључености су у великој мери маргинализоване током првих 15 година транзиције. Биле су доступне анализе незапослености, деиндустријализације и либерализације, притиска на социјална права, индекса људског развоја и појединих социјалних проблема, али су научне расправе о сиромаштву у највећој мери биле непожељне и посматране кроз идеолошке предрасуде као супротне идејама о тржишту и демократији.

Захваљујући интеграцији Бугарске у ЕУ и експанзији упоредних статистика о сиромаштву, идеолошки притисак је донекле смањен, а све је већи број националних анализа и истраживања, укључујући и оне које се односе на разне проблеме сиромаштва, његове разне димензије и видове испољавања, као и на усредсређивање на разне групе изложене сиромаштву. Истовремено су бугарски актери и организације успоставили контакт и постали део разних широких мрежа ЕУ (на пример, EuroChild, Европска мрежа против сиромаштва итд.), а појавила су се и упоредна истраживања конкретних питања. Увођење званичне линије сиромаштва, проглашавање 2010. за европску годину против сиромаштва, интензивирање синдикалних активности и оснивање разних тела задужених за питања сиромаштва, попут Националног економског и социјалног одбора, подстакло је спровођење разних студија и анализа.

За трећу деценију периода транзиције карактеристични су експанзија и продубљивање анализа, заједно са потрагом за могућим решењима за новонастале проблеме и разним предлозима за промене у јавној политици у овој области. Исто тако, интензивирају се и проширују јавне расправе. Разне области социјалне политике све више су предмет пажње истраживања и анализа: а) тржиште рада (Borisova-Marinova et al, 2018; Jeliazkova, Minev, Draganov, 2018; Krasteva, 2019; Jeliazkova, 2019); б) образовање (Milenkova, 2011; Kabakchieva, 2018); в) здравство (Ivkov et al, 2017; Ivkov, 2018); г) социјалне бенефиције (Grigorova, 2016; Grigorova, 2018); д) енергетско сиромаштво (Zahariev et al, 2016; Peneva, 2019); ђ) пореска политика (Minev, 2018; Pekanov, 2018) итд. 
Упркос овим позитивним трендовима, требало би навести и извесне недостатке постојећих анализа и истраживања.

А) Може се рећи да је већина анализа углавном дескриптивног карактера. Националне статистике и резултати емпиријских социолошких анкета, као и упоредна истраживања Бугарске и осталих чланица ЕУ, укључујући и просечне вредности у ЕУ, изузетно су важан основ за кратке приказе и закључке, као и за развој предлога за промене. У исто време, фрагментарни подаци, недостатак развијених адекватних национално прилагођених дефиниција, показатеља и података о трошковима живота отежавају стицање јасне и поуздане представе о сиромаштву.

Б) Важна одлика података и анализа јесте наглашавање фактора који прате сиромаштво - као што су ниво образовања, запослење и статус на тржишту, састав и структура домаћинстава, насеља, етничка селективност, године старости итд. Ово доприноси фрагментацији група и проценама на основу појединачних случајева или програма, али отежава развој теоретских и практичних перспектива за значајно смањење сиромаштва, што је иначе установљени циљ политика и суштина истраживања и анализа.

Иако су ти пратећи фактори важан део представе о сиромаштву у земљи, расправа о њима као о главним узроцима сиромаштва и маргинализације говори о посебној селективности истраживачких тема уместо о постепеном самосталном унапређењу истраживања и анализа. Ово, у ствари, доводи до празнина и недостатка показатеља у истраживачким пољима и ограничава могућност унапређивања већ развијених предлога и њихову научну расправу.

В) Недостају подаци о неким адекватним показатељима, као што су линија сиромаштва, односно преживљавања; куповна моћ у погледу различитих износа дохотка; неједнакости у оквиру одређених група, нпр. Рома, мушкараца, жена; неједнакости 90/10; неједнакости 99/1; концентрација богатства итд. Тај недостатак података не обезбеђује довољан основ за даље унапређење истраживања и анализа.

Г) Нема ни довољно научних процена о доследности политика против сиромаштва са осталим типовима политика - попут оних из области економије, енергетике, заштите животне средине, те финансијске, регионалне и пољопривредне политике.

Д) У исто време, доступне анализе сиромаштва и предлози засновани на њима немају довољно простора ни у научним расправама нити се примењују у спроведеним политикама. Стога су могућности научне анализе важних питања прилично ограничене. Пример за ово јесте чињеница да се постојећи научни програми (усвојени 2018), који треба да створе услове за тражење и проналажење решења за текуће и важне друштвене изазове, промене, уопште не баве питањима благостања 5 . Упркос томе што је Бугарска очигледно међу земљама са најнеповољнијим

\footnotetext{
5 Усвојени су следећи национални истраживачки програми: „Информационе и комуникационе технологије за јединствено дигитално тржиште у науци, образовању и безбедности”; „Нискоугљенична енергија за транспорт и домаћинства”; „Заштита животне средине и смањивање ризика од негативних догађаја и природних непогода”; „Здрава храна за снажну биоекономију и квалитет живота”; „Културно и историјско наслеђе, национално памћење и друштвени развој”; „Електронска здравствена заштита” и „Репродуктивне биотехнологије у сточарству".
} 
нивоима већине показатеља благостања, ови изазови нису установљени као приоритетна научна питања, бар када је реч о националним истраживачким програмима.

Ђ) Поред тога, чини се да постоји демотивишући ефекат све док нема јасних механизама за претварање научних резултата у практичне активности. Недостатак независних оцена ситуације и спроведених политика, као и недостатак такозваних партиципативних истраживања, уз учешће заинтересованих појединаца односно страна, обесхрабрују научна истраживања ових проблема.

Е) Главни резултат оваквог споја претежно дескриптивних анализа, наглашавања већ поменутих пратећих фактора, фрагментарне оцене о разним мерама на тржишту рада и шемама социјалне помоћи, знања ограниченог финансијским и имплементационим токовима, представља препреку за сазнања о главним генераторима сиромаштва и о томе како се њима треба позабавити.

Посматрајући преовлађујуће предрасуде, изгледа да су димензије сиромаштва у Бугарској, спроведене политике и у одређеној мери квалитет анализа у функционалној кореспонденцији и да се донекле међусобно подржавају.

\section{Закључак и предлог политике}

Бугарска има крајње озбиљне проблеме са сиромаштвом и социјалном искљученошћу, праћене дубоком маргинализацијом одређених група и континуираним сиромаштвом које се преноси са генерације на генерацију. Као што је илустровано у првом делу овог рада, предузете мере не доприносе значајно превазилажењу сиромаштва и социјалне искључености у земљи. У том смислу, треба признати неадекватност доступних политичких мера, а уместо пуког прилагођавања, постојеће политике треба из корена ревидирати. Важан разлог за то јесте да, иако се о њима ретко расправља, главни генератори сиромаштва у земљи јесу бројне политике - економска, финансијска, образовна, здравствена, пореска и политика социјалне заштите, као и односи између њих. На основу тога, социјална политика у одређеним аспектима ипак настоји да ублажи неповољне процесе проузроковане другим политикама и делује као крајње средство пружајући подршку људима са најнижим приходима и обезбеђујући изузетно низак степен бенефиција.

Да би се превазишли ови проблеми, неопходна је јасна доследност између различитих политика заснованих на адекватним показатељима социјалних бенефиција и благостања и усмерених на генераторе сиромаштва и економски раст у корист сиромашних. У том смислу, неопходно је спровести циљану ревизију, анализу и процену разних политика, а независне оцене социјалног утицаја требало би да допринесу одлучном унапређењу у свим фазама циклуса политике (утврђивање програма, препознавање циљева, развој одговарајућих инструмената за остваривање тих циљева, примена установљених инструмената, процена и научна анализа начина поступања са генераторима сиромаштва).

Преусмеравање са знања мотивисаног политиком на политике засноване на знању могао би да обезбеди холистички, интегрисан развој усредсређен на људе, са адекватним акцијама против сиромаштва. 


\section{REFERENCES / ЛИTЕРATУPA:}

Borisova-Marinova, K. et al. (2018). Demographic Development, Labour Force and Labour Resources in Bulgaria, In: ISPP-BAS, Measures to Overcome the Demographic Crisis in Republic of Bulgaria, vol. 4, Sofia [In Bulgarian ]

EC (2018). Employment and Social Developments in Europe, Annual Review 2018

Eurostat (2020a). At-risk-of-poverty rate by poverty threshold, age and sex-EU-SILC and ECHP surveys [ilc_li02], Extracted on 27/09/2020

Eurostat (2020b). Children at risk of poverty or social exclusion [ilc_peps01], downloaded $4 / 01 / 2021$

Eurostat (2020c). Gini coefficient of equivalised disposable income after social transfers EU-SILC survey [ilc_di12]

Eurostat (2020d). Gini coefficient of equivalised disposable income before social transfers (pensions included in social transfers) [ilc_di12b]

Eurostat (2020e). In-work at-risk-of-poverty rate by age and sex - EU-SILC survey [ilc_ iw01], downloaded 04/01/2021

Eurostat (2020f). Material and social deprivation rate by age, sex and most frequent activity status [ilc_mdsd01], downloaded on 04/01/2021

Eurostat (2020g). People at risk of poverty or social exclusion; https://ec.europa.eu/eurostat/ databrowser/view/SDG_01_10/default/table_Data extracted on 18/09/2020

Eurostat (2020h). Persistent at-risk-of-poverty rate by sex and age - EU-SILC and ECHP surveys [ilc_li21], downloaded on 04/01/2021

Eurostat (2020i). Severely materially deprived people [SDG_01_30], data extracted on $18 / 09 / 2020$

Eurostat (202j), Severe material deprivation rate, analysed by age, 2015-2019, Data extracted on $04 / 01 / 2020$

Grigorova, V. (2018). The people against social benefits: or the art of making the needy themselves demand more restrictions against themselves. Sofia: Public Intervention Team [In Bulgarian ]

Grigorova, V. (2016). Poor vs. Poor, Sofia: Collective for Public Interventions [In Bulgarian ]

Ivkov, B. (2018). Socio-economic stratification and social inequalities in health. Report presented at a round table on "Inequalities and poverty in Bulgaria" under the patronage of the President of the Republic of Bulgaria, held on October 9, 2018 [In Bulgarian ]

Ivkov, B., Atanasov, A., Saykova, S., Toneva, Z., Todorova, S., Popivanov, P., Draganov, D., Yankov, I., Ampirska, T. (2017) Health expenditures from pocket and health inequalities. UNWE, Sofia

Jeliazkova, M. (2019). Quality of jobs and employment in Bulgaria, in: Population Journal, 37, 4/2019, Publishing House of BAS [In Bulgarian ]

Jeliazkova, M. \& Minev, D. (2020). Bulgaria: Poverty Watch 2020, https://www.eapn.eu/ wp-content/uploads/2020/10/EAPN-EAPN-Bulgaria-Poverty-Watch-2020_ENG4747.pdf

Jeliazkova, M., Minev, D. \& Draganov, D. (2018). Assessing youth employment policies in 28 European countries, EXCEPT Working Papers, WP No. 55. Tallinn University, Tallinn. http://www.except-project.eu/working-papers/ 
Kabakchieva, P. (2018). The quality of education - for whom? Normative visions for the quality and practical differentiation of schools. Report presented at the Annual Scientific Conference of BAS: Inequalities in Bulgaria: Causes, Consequences, Manifestations, held on December 11, 2018, Sofia [In Bulgarian ]

Krasteva, V. (2019). Youth employment and precarious jobs: the case of Bulgaria, Publishing House of BAS [In Bulgarian ]

Living Wage Indicator, https://wageindicator.org/salary/living-wage/bulgaria-living-wage -series-september-2019

Milenkova, V. (2011). Educational inequalities in the context of Bulgarian modernity, in

Problems of postmodernity, 1 [In Bulgarian ]

Minev, D. (2018). Abnormal inequalities: mechanisms that cause them, their consequences and opportunities for their reduction, Report presented at a round table on "Inequalities and poverty in Bulgaria" under the patronage of the President of the Republic of Bulgaria, held on 09/10/2018 [In Bulgarian ]

National Strategy for Poverty Reduction and Promotion of Social Inclusion 2030, http:// www.strategy.bg/StrategicDocuments/View.aspx?lang=bg-BG\&Id=790

NSI (2019). National Statistical Institute on Indicators of Poverty and Social inclusion in 2019, https://www.nsi.bg/[In Bulgarian ]

Numbeo, https://www.numbeo.com/cost-of-living/in/Sofia

Pekanov, A. (2018). Economic inequalities in Bulgaria in a European context and their macroeconomic consequences, Report presented at a round table on "Inequalities and poverty in Bulgaria" under the patronage of the President of the Republic of Bulgaria, held on 09/10/2018 [In Bulgarian ]

Peneva, T. (2019). Energy poverty in Bulgaria, in Yearbook of the Faculty of Economics and Business Administration, Sofia University, vol. 1 [In Bulgarian ]

Social Assistance Act, https://lex.bg/laws/ldoc/2134405633 [In Bulgarian ]

Zahariev, B., Grigorova, V. \& Yordanov, I. (2016). Energy Poverty in Bulgaria, Open Society Sofia [In Bulgarian ] 


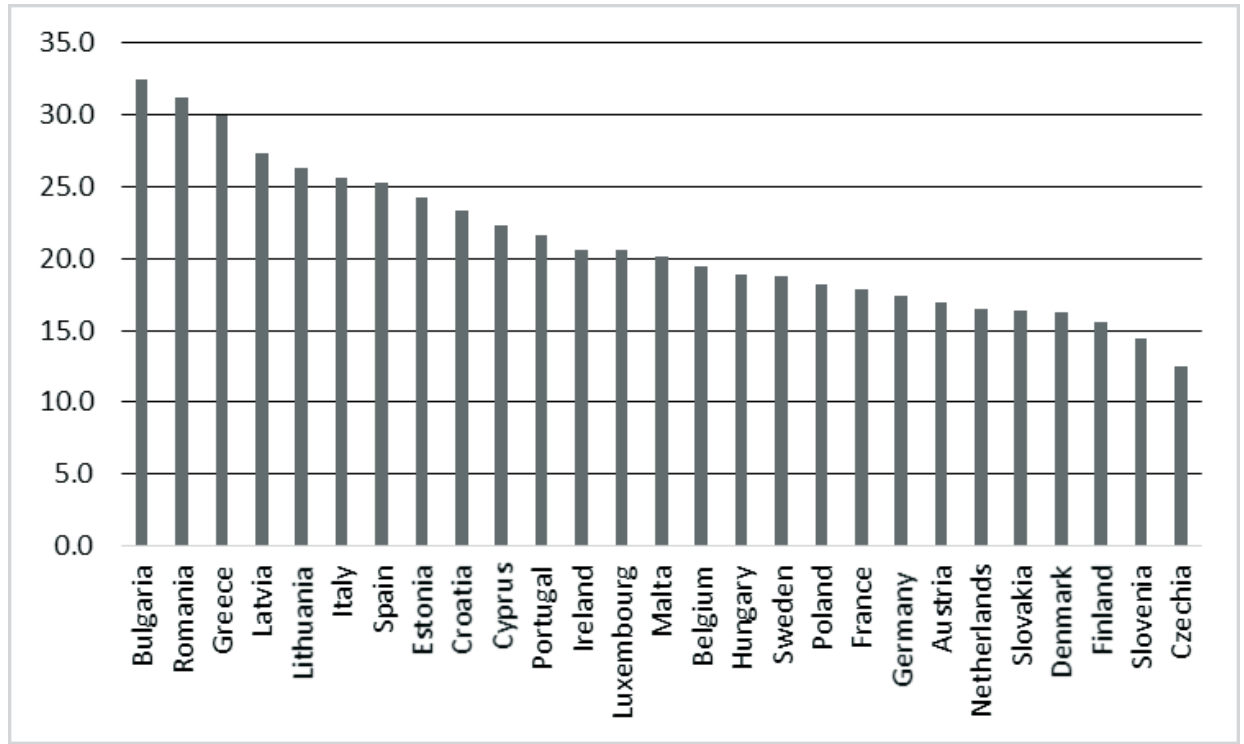

Graph 1. Share of people at risk of poverty or social exclusion: $2019^{6} /$

Графикон 1. Удео људи изложених ризику од сиромаштва или социјалне искључености, 2019. ${ }^{6}$

Table 1 . At risk of poverty rate - cut-off point: $60 \%$ of median equivalised income after social transfers ${ }^{7}$ / Табела 1. Стопа ризика од сиромаштва - тачка пресека: $60 \%$ средњег прилагођеног прихода после социјалних трансфера ${ }^{7}$

\begin{tabular}{|c|c|c|c|c|c|c|c|c|c|c|c|c|c|}
\hline \multirow{2}{*}{ — BACK } & Year/Година & 2008 & 2009 & 2010 & 2011 & 2012 & 2013 & 2014 & 2015 & 2016 & 2017 & 2018 & 2019 \\
\hline & \begin{tabular}{|l|} 
EU-28 / EY-28 \\
$(2013-2020)$
\end{tabular} & - & - & 16,5 & 16,9 & 16,8 & 16,7 & 17,2 & 17,3 & 17,3 & 16,9 & 17,1 & - \\
\hline & $\begin{array}{l}\text { Bulgaria/ } \\
\text { Бугарска }\end{array}$ & 21.4 & 21.8 & 20,7 & 22,2 & 21,2 & 21,0 & 21,8 & 22,0 & 22,9 & 23,4 & 22,0 & 22,6 \\
\hline
\end{tabular}

\footnotetext{
${ }^{6}$ Source: Compiled by the author based on data from Eurostat (2020g)

6 Извор: Ауторкина компилација података добијених од Eurostat-a

7 Source: Compiled by the author based on data from Eurostat (2020a)

7 Извор: Ауторкина компилација података добијених од Eurostat-a
} 


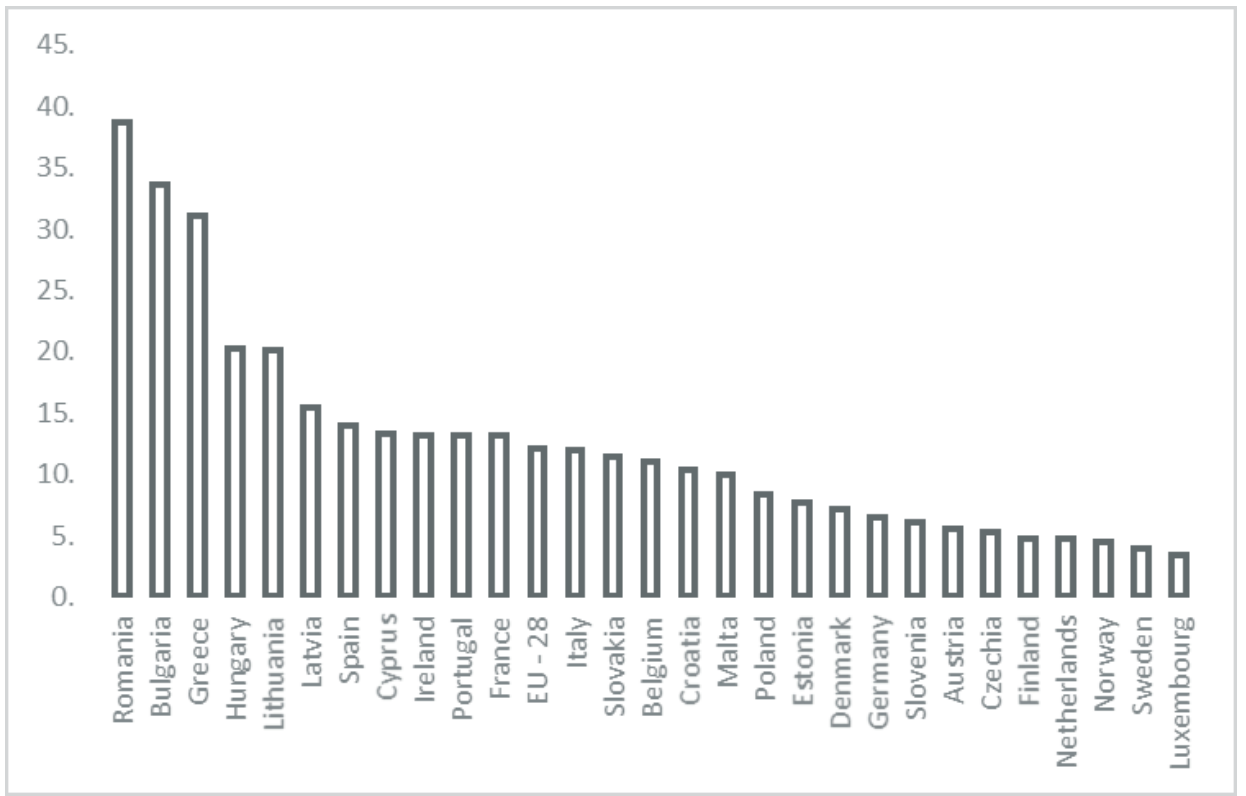

Graph 2. Material and Social Deprivation Rate, 20198/

Графикон 2. Стопа материјалне и социјалне ускраћености, $2019^{8}$.

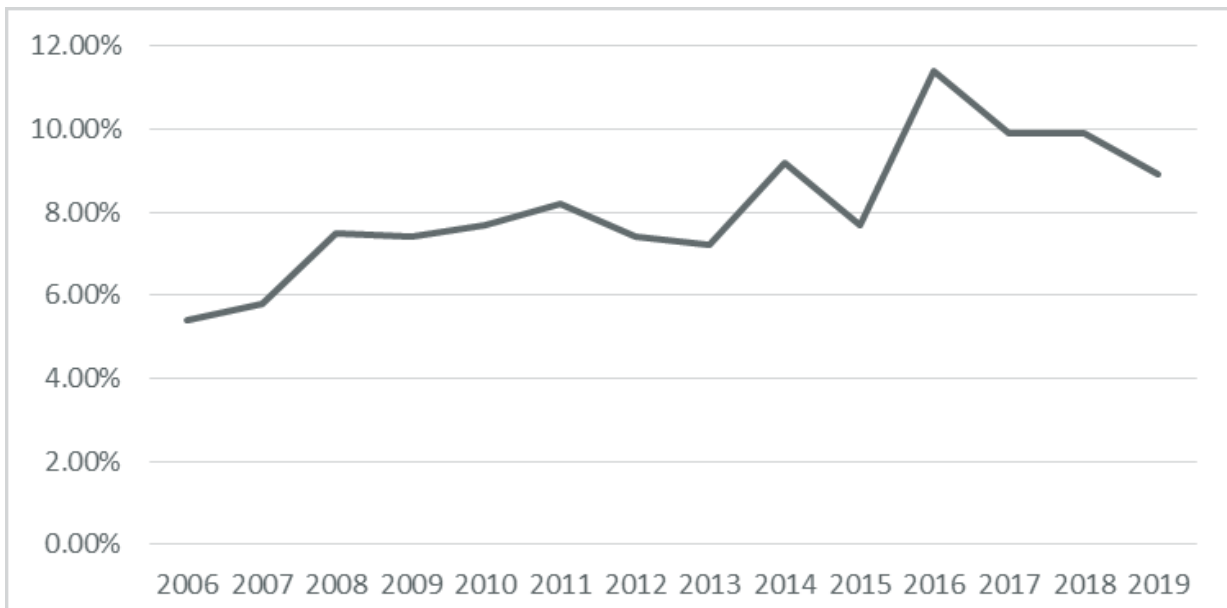

Graph 3. In-work at-risk-of-poverty rate in Bulgaria ${ }^{9}$

Графикон 3. Стопа ризика од сиромаштва међу запосленима у Бугарској ${ }^{9}$

8 Source: Compiled by the author based on data from Eurostat (2020f)

8 Извор: Ауторкина компилација података добијених од Eurostat-a

9 Source: Compiled by the author based on data from Eurostat (2020e)

9 Извор: Ауторкина компилација података добијених од Eurostat-a 


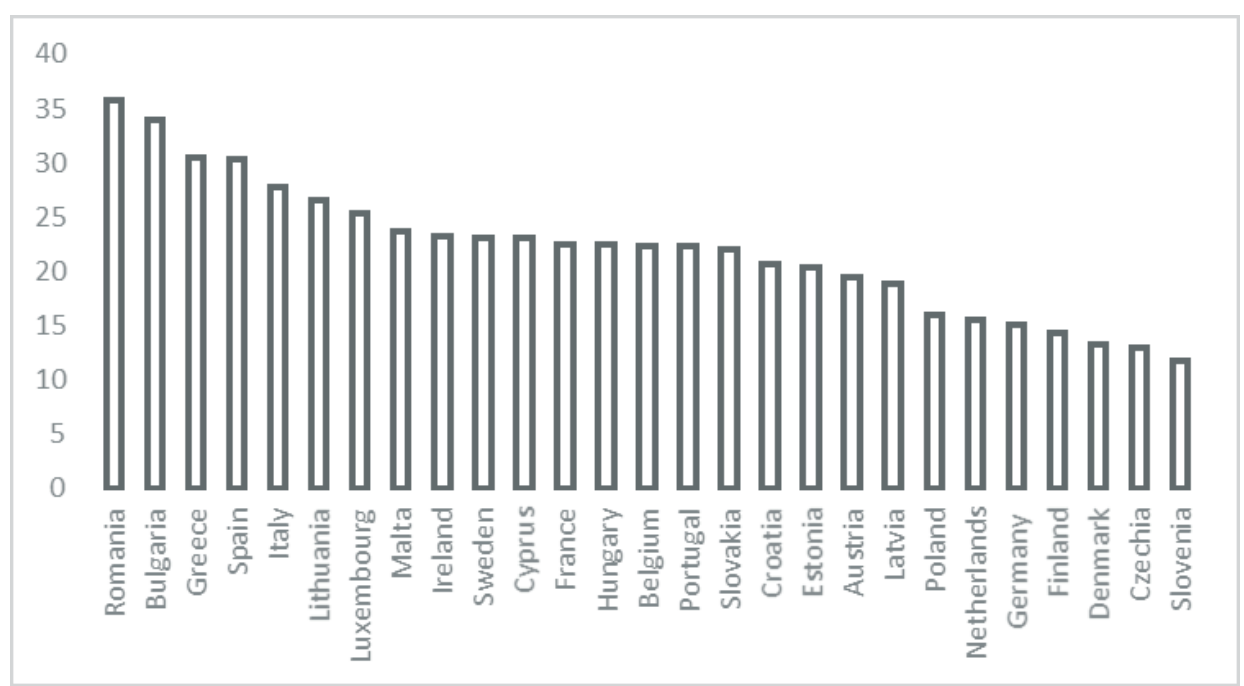

Graph 4. Children at-risk-of-poverty or social exclusion in EU in $2019^{10} /$

Графикон 4. Деца изложена ризику од сиромаштва или социјалне искључености у EУ 2019. ${ }^{10}$

Table 2. Material and social deprivation rate of retired people $\mathrm{e}^{11} /$

Табела 2. Стопа материјалне и социјалне ускраћености међу пензионерима ${ }^{11}$

\begin{tabular}{|l|c|c|c|}
\hline & $\begin{array}{c}65 \text { years or over/ } \\
65 \text { година или } \\
\text { старији }\end{array}$ & $\begin{array}{c}75 \text { years or over/ } \\
75 \text { година или } \\
\text { старији }\end{array}$ & $\begin{array}{c}85 \text { years or over/ } \\
85 \text { година или } \\
\text { старији }\end{array}$ \\
\hline $\begin{array}{l}\text { EU-28 average/ } \\
\text { ЕУ-28 просек }\end{array}$ & 10,7 & 10,2 & 10,3 \\
\hline Bulgaria/Бугарска & 50,8 & 54,4 & 52,4 \\
\hline
\end{tabular}

10 Source: Compiled by the author based on data from Eurostat (2020b)

10 Извор: Ауторкина компилација података добијених од Eurostat-a

11 Source: Compiled by the author based on data from Eurostat (2020f)

11 Извор: Ауторкина компилација података добијених од Eurostat-a 
Table 3. Share of employees with salaries/wages as $\%$ of the average salary ${ }^{12}$ /

Табела 3. Удео запослених са платама/надницама као проценат просечних примања ${ }^{12}$

\begin{tabular}{|c|c|c|}
\hline $\begin{array}{c}\text { Share of the average salary/Удео } \\
\text { просечних примања/ }\end{array}$ & $\begin{array}{c}\text { Bulgaria/ } \\
\text { Бугарска/ }\end{array}$ & $\begin{array}{c}\text { Czech Republic/Чешка } \\
\text { Република / }\end{array}$ \\
\hline Up to 40\% / До 40\% & 10.6 & 2.2 \\
\hline $40-50 \%$ & 5.4 & 2.3 \\
\hline $50-60 \%$ & 7.4 & 4.6 \\
\hline $60-70 \%$ & 6.7 & 7.8 \\
\hline $71-129 \%$ & 36.2 & 57.3 \\
\hline $130-140 \%$ & 4.8 & 5.5 \\
\hline $140-150 \%$ & 3.2 & 4 \\
\hline $150-160 \%$ & 3.3 & 3.6 \\
\hline Over 160\%/Преко 160\% & 22.4 & 12.7 \\
\hline & 100 & 100 \\
\hline
\end{tabular}
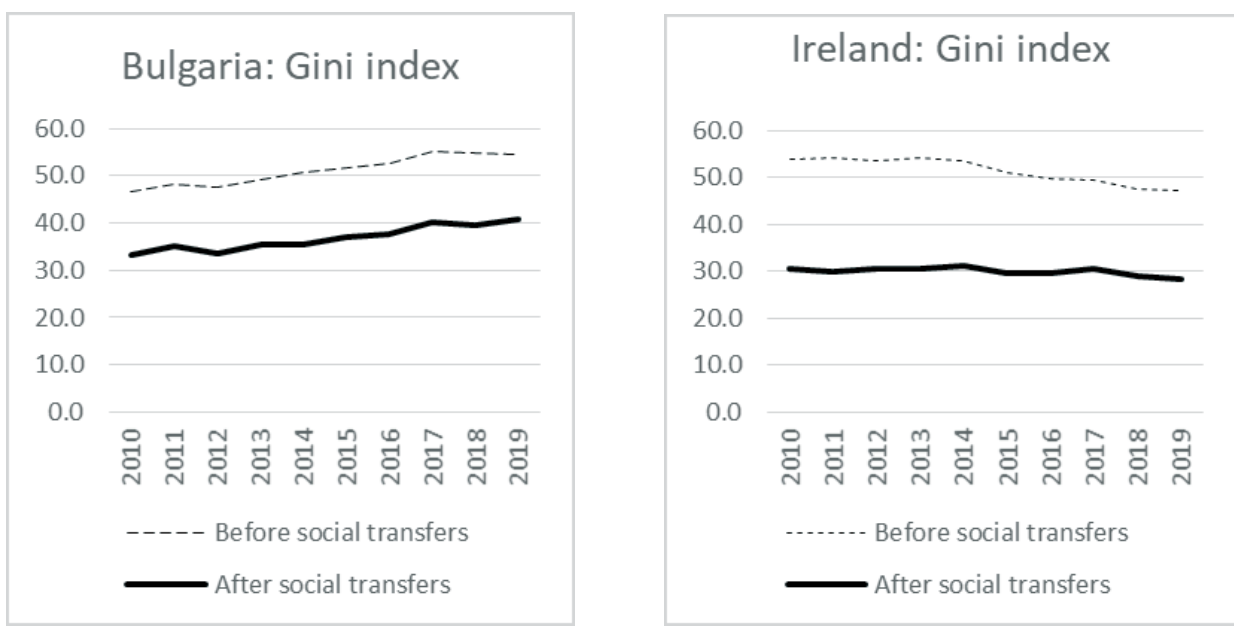

Graph 5. Gini index in Bulgaria and Ireland 2010-201913/

Графикон 5. Ђини коефицијент у Бугарској и Ирској у периоду 2010-2019. ${ }^{13}$

\footnotetext{
12 Source: EC 2018

12 Извор: Европска комисија

13 Извор: Ауторкина компилација података добијених од Еуростат-а

13 Source: Compiled by the author based on data from Eurostat (2020c \& d)
} 


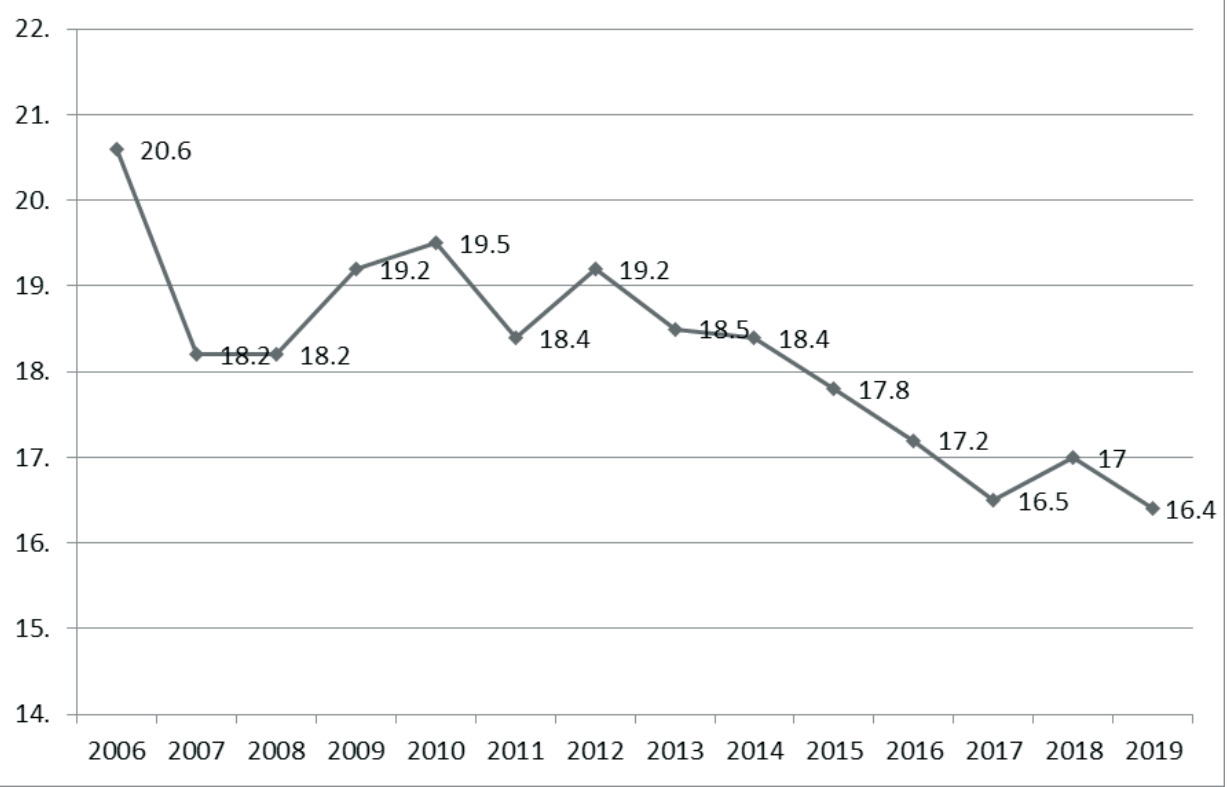

Graph 6. Bulgaria - Income share of the bottom $40 \%$ of the population 2006-201914 / Графикон 6. Бугарска - удео прихода најсиромашнијих 40\% становништва Бугарске у периоду 2006-2019. ${ }^{14}$

14 Source: Compiled by the author based on data from Eurostat 2020 [SDG_10_50]

14 Извор: Ауторкина компилација података добијених од Eurostat-a 